\title{
Upaya Meningkatkan Prestasi Belajar PPkn Melalui Penggunaan Model Pembelajaran Pair Check
}

\section{Made Arka*}

\author{
A R T I C L E I N F O \\ Article history: \\ Received 12 February \\ 2020 \\ Received in revised form \\ 18 March 2020 \\ Accepted 30 April 2020 \\ Available online 27 May \\ 2020 \\ Kata Kunci: \\ Model Pembelajaran Pair \\ Check, Prestasi Belajar \\ Siswa \\ Keywords: \\ Pair Check Learning \\ Model, Student Learning \\ Achievement
}

\begin{abstract}
A B S T RAK
Tujuan dari penelitian ini adalah untuk mencapai peningkatan presatasi belajar melalui model pembelajaran pear check. Yang menjadi subjek penelitian ini adalah siswa kelas IX A, pada semester I, tahun pelajaran 2018/2019 SMP Negeri 1 Blahbatuh. Metode pengumpulan data yang digunakan adalah metode tes prestasi belajar. Setelah diperoleh data, lalu dilakukan analisis menggunakan analisis deskriptif. Setelah pelaksanaan tindakan, data yang penulis dapatkan menunjukkan peningkatan yang baik, dari awalnya baru mencapai rata-rata 67,82 , padasiklus I meningkat menjadi 73,46 dan pada siklus II meningkat menjadi 80,12. Dengan perolehan peningkatan hasil tersebut dapat disampaikan bahwa dengan menerapkan Model Pembelajaran Pair Check dapat meningkatkan prestasi belajar PPKn siswa kelas IX A SMP Negeri 1 Blahbatuh Semester I Tahun Pelajaran 2018/2019.
\end{abstract}

\section{A B S T R A C T}

Students studying in Class IX A, in semester I, 2018/2019 academic year of SMP Negeri 1 Blahbatuh, were used as objects of research aimed at achieving improved learning achievement. The data that is sought to be collected is collected with the results of learning. After the data is obtained, an analysis is carried out using descriptive analysis. After the implementation of the action, the data that the writer got showed a good improvement, from the beginning it only reached an average of 67.82, in the first cycle increased to 73.46 and in the second cycle increased to 80.12. With the acquisition of the increase in results it can be said that by applying the Pair Check Learning Model can improve the learning achievement of PPKn grade IX A students of SMP Negeri 1 Blahbatuh I Semester 2018/2019 Academic Year. 


\section{Pendahuluan}

Pendidikan adalah sebuah sistem. Sebagai sistem, aktivitas pendidikan terbangun dalam beberapa komponen, yaitu pendidik, peserta didik, tujuan pendidikan, alat pendidikan, dan lingkungan pendidikan. Semua komponen yang membangun sistem pendidikan, saling berhubungan, saling tergantung, dan saling menentukan satu sama lain. Setiap komponen memiliki fungsi masing-masing dalam rangka mencapai tujuan pendidikan. Aktivitas pendidikan akan terselenggara dengan baik apabila didukung oleh komponen-komponen dimaksud. Fungsi pendidikan sebenarnya adalah menyediakan fasilitas yang dapat memungkinkan tugas pendidikan dapat berjalan lancar, baik secara struktural, maupun secara institusional. Secara struktural menuntut terwujudnya struktur organisasi yang mengatur jalannya proses kependidikan. Secara institusional mengandung implikasi bahwa proses kependidikan yang terjadi dalam struktur organisasi itu dilembagakan untuk lebih menjamin proses pendidikan itu berjalan secara konsisten dan berkesinambungan mengikuti kebutuhan dan perkembangan manusia yang cenderung ke arah tingkat kemampuan yang optimal (Saat, 2015).

Pendidikan merupakan sesuatu yang memiliki tujuan yang sangat penting untuk diperoleh. Dalam skala nasional, tujuan dalam pendidikan adalah untuk mengembangkan kemampuan dan membentuk watak serta peradaban bangsa yang bermartabat dalam rangka mencerdaskan kehidupan bangsa, serta untuk mengembangkan potensi peserta didik agar menjadi manusia yang beriman dan bertakwa kepada Tuhan Yang Maha Esa, berakhlak mulia, sehat, berilmu, cakap, kreatif, mandiri, dan menjadi warga negara yang demokratis serta bertanggung jawab. Artinya bahwa tujuan pendidikan adalah membentuk orang yang mempunyai sikap atau attitude sosial yang baik, yang mampu bekerja sama dengan lingkungannya, mampu mengutamakan kepentingan umum dari pada kepentingan sendiri atau golongan. Sedangkan fungsi diadakannya pendidikan dalam pandangan dalam Islam

tidaklah jauh berbeda dengan yang ada pada tujuan pendidikan nasional di atas, dimana pendidikan tidak hanya untuk pembentukan akal atau pengembangan kompetensi para siswa saja, melainkan berfungsi juga kepada setiap bagian jiwa sehingga setiap bagian jiwa itu menjadi mampu melaksanakan tugasnya sebagaimana yang dikehendaki Allah SWT. Dalam proses pencapaian tujuan pendidikan, siswa sebagai subyek pendidikan dapat diarahkan kepada suatu pendidikan formal dan informal. Pendidikan formal merupakan suatu jalur pendidikan yang terstruktur dan berjenjang yang terdiri atas pendidikan dasar, pendidikan menengah, dan pendidikan tinggi. Sedangkan pendidikan informal adalah jalur pendidikan di luar pendidikan formal. Dalam arti tidak dilaksanakan secara struktur dan berjenjang seperti bimbingan-bimbingan belajar, kursus, dan lain sebagainya (Thahir, 2014).

Pendidikan memegang peranan penting dalam mempersiapkan sumber daya manusia yang berkualitas dan mampu berkompetisi dalam perkembangan ilmu pengetahuan dan teknologi, sehingga pendidikan harus dilaksanakan dengan sebaikbaiknya untuk memperoleh prestasi belajar yang maksimal. Hal tersebut dapat dicapai dengan terlaksananya pendidikan yang tepat waktu dan tepat guna untuk mencapai tujuanp pembelajaran. Pembelajaran matematika di sekolah merupakan salah satu komponen pendidikan yang tidak hanya mengembangkan kemampuan dan keterampilan menerapkan matematika, melainkan mengembangkan kemampuan memecahkan masalah. Pada umumnya, prestasi belajar matematika siswa masih jauh dari harapan, meskipun untuk perorangan prestasi belajar mampu mencapai taraf optimal. Dari observasi awal yang dilakukan pada siswa kelas VII A di SMP N 1 Polanharjo, ratarata prestasi belajar matematika siswa cukup rendah dibandingkan dengan mata pelajaran yang lain. Dari pengamatan dan informasi yang diperoleh menunjukkan prestasi belajar siswa kelas VII A masih cukup rendah.

Guru bidang studi matematika lebih banyak menggunakan model pembelajaran konvensional. Dalam model tersebut proses pembelajaran berpusat pada guru sehingga peserta didik tidak dapat berperan secara aktif dalam pembelajaran. Selanjutnya peserta didik diarahkan untuk menghafal berbagai rumus, tanpa didukung pemahaman dan pengertian yang tepat sehingga kegiatan belajar menjadi tidak mampu mencapai tujuan yang diharapkan. Kebiasaan menghafalkan rumus dan berlatih menyelesaikan soal pada akhirnya berdampak negatif terhadap minat belajar siswa. Minat seorang siswa mempengaruhi prestasi belajarnya. Menurut Slameto (2010:57), Minat adalah kecenderungan yang tetap untuk memperhatikan dan mengenang beberapa kegiatan. Oemar Hamalik (2009:105), menuliskan bahwa guru perlu sekali mengenal minatminat muridnya, karena ini penting bagi guru untuk memilih bahan pelajaran, merencanakan pengalaman-pengalaman belajar, menuntun mereka kearah pengetahuan, dan untuk mendorong motivasi belajar mereka. Prestasi belajar sebagai produk akhir kegiatan belajar, tidaklah diperoleh dengan cara dan prosedur sederhana, namun prestasi belajar merupakan gambaran menyeluruh dari kegiatan yang dilakukan siswa baik aktifitas mental dan spiritual. Menurut Kamus Besar Bahasa Indonesia (2007:1101), "Prestasi adalah hasil yang telah dicapai dari yang telah dilakukan atau dikerjakan". Tingkat pencapaian hasil belajar oleh siswa disebut hasil belajar (Wijayanti, 2014). 
Keberhasilan proses pembelajaran lebih banyak ditentukan oleh kemampuan guru dalam mengelola proses pembelajaran tersebut. Kadang ada guru yang disebut pintar tetapi lemah dalam menyampaikan pengetahuan dan pemahaman yang ada dalam dirinya maka tentu proses pembelajaran tidak akan berhasil dengan baik. Kadang ada guru yang disebut tidak terlalu pintar tetapi dalam menyampaikan dan mengelola pembelajaran lebih kreatif dan memahami cara penyampaiannya bisa jadi menyebabkan proses pembelajaran akan berhasil dengan baik. Di antara keduanya tentu yang paling sesuai adalah memiliki kemampuan profesionalisme keguruan dan mampu menyampaikan dengan baik demi terciptanya proses dan tujuan pembelajaran yang diharapkan untuk mampu meningkatkan ketakwaan terhadap Tuhan Yang Maha Esa.

Sehubungan dengan proses pembelajaran yang berlangsung di SMP Negeri 1 Blahbatuh dari hasil pengumpulan data awal didapat nilai rata-rata siswa kelas 67,82 pada mata pelajaran PPKN baru mencapai 51,28\%. Hasil tersebut tentu tidak sesuai dengan harapan keberhasilan pendidikan yang ditetapkan. Tentang pelajaran yang disampaikan, jika pelajaran sempat diterima peserta didik dan belum berhasil, boleh jadi penyebabnya dikarenakan keterbatasan kemauan guru dalam menerapkan semua keilmuan yang dikuasai demi pencapaian hasil maksimal dalam pembelajaran. Sedangkan dari pihak siswa banyak dipengaruhi oleh kebiasaan belajar mereka yang rendah akibat pengaruh luar, kemampuan ekonomi orang tua dan kebiasaan belajar yang belum banyak dipupuk. Namun apapun yang menjadi latar belakang permasalahan, apabila hal ini dibiarkan berlarut tentu berakibat tidak baik bagi kelangsungan pendidikan peserta didik dan bagi perkembangan mutu pendidikan bangsa Indonesia. Karena hal tersebut di atas merupakan sesuatu yang mendesak untuk dipecahkan menuntut guru lebih kreatif dan inovatif mencari jalan keluar dengan melakukan penelitian yang berguna demi meningkatkan kualitas pendidikan di sekolah.

Melihat kesenjangan antara harapan-harapan yang telah disampaikan dengan kenyataan lapangan sangat jauh berbeda, dalam upaya memperbaiki mutu pendidikan utamanya pada mata pelajaran PPKn, sangat perlu kiranya dilakukan perbaikan cara pembelajaran. Salah satunya adalah perbaikan pembelajaran dengan menggunakan model pembelajaran Pair Check.

Model pembelajaran Pair Check merupakan salah satu dari banyak cara yang bisa dilakukan guru dalam upaya meningkatkan mutu pembelajaran. Model ini mempunyai langkah-langkah yang mendorong keaktifan siswa dalam belajar dengan cara memberikan kesempatan bagi siswa untuk siap tampil dihadapan teman-temannya. Untuk mampu tampil dihadapan orang banyak bukanlah hal yang gampang. Untuk mampu tampil dihadapan orang banyak bukanlah hal yang gampang. Hal itu memerlukan persiapan yang matang. Untuk persiapan yang matang ini, guru memberikan kesempatan yang sebanyakbanyaknya, guru memberi kesempatan agar siswa menyiapkan sebaik-baiknya apa yang akan ditampilkan dihadapan siswa-siswa yang lain. Model pembelajaran Pair Check ini mampu merangsang siswa untuk dapat bertanggung jawab terhadap pekerjaannya, menuntut persiapan yang sangat matang, menuntut kemampuan yang matang dalam presentasi, menutut semangat yang tinggi untuk mengikuti pelajaran agar dapat mempersiapkan tampilan yang diharapkan, menuntut sebab akibat dari pelaksanaan diskusi. Contoh sebab akibat tersebut adalah, apabila siswa giat mengikuti pelajaran, akibatnya adalah mampu memberi tampilan yang diharapkan. Siswa akan menjadi aktif akibat diberikan giliran untuk berbicara di depan teman-temannya, yang sudah pasti akan menimbulkan tuntutan-tuntutan kemampuan yang tinggi baik dalam penampilan maupun keilmuan. Tanpa keilmuan yang mencukupi tidak akan mungkin tampilannya akan memuaskan, dalam hal ini siswa tidak bisa sembarangan saja, mereka harus betul-betul mampu menyimpulkan terlebih dahulu apa yang mereka akan bicarakan. Tuntunan langkah-langkah, motivasi, interpretasi yang inovatif dipihak guru akan menentukan keberhasilan pelaksanaan model ini.

Berdasarkan pemaparan di atas, maka pada penelitian ini akan mengambil judul tentang Upaya Meningkatkan Prestasi Belajar PPKN Melalui Penggunaan Model Pembelajaran Pair Check Pada Siswa Kelas IX A SMP Negeri 1 Blahbatuh Semester I Tahun Pelajaran 2018/2019.

Hipotesis tindakan dalam penelitian ini dapat dirumuskan: Apabila Model Pembelajaran Pair Check dilaksanakan dengan maksimal maka dapat meningkatkan prestasi belajar PPKn siswa Kelas IX A SMP Negeri 1 Blahbatuh Semester I Tahun Pelajaran 2018/2019.

\section{Metode}

Penelitian yang dilakukan termasuk penelitian tindakan. Oleh karenanya, rancangan yang khusus untuk sebuah penelitian tindakan sangat diperlukan. Berdasarkan sudut pandang pencapaian tujuan penelitian, rancanganpenelitian berfungsi sebagai pedoman kerja (peta pedoman pengarahan bagipelaksanaan penelitian). Oleh karenanya, rancangan penelitian harus jelas,singkat dan memberikan petunjuk operasional tentang apa yang sebaiknyadilakukan dan bagaimana cara serta teknik melakukannya. Fungsi lain,rancangan penelitian adalah sebagai rambu-rambu penentuan atau tolok 
ukurkeberhasilan penelitian yang akan dilaksanakan. Memberikan petunjuk mengenaiukuran-ukuran sampai dimana penelitian yang dilakukan itu dikatakan mencapaihasil yang diinginkan.

Untuk penelitian ini penulis memilih rancangan penelitian tindakan yang disampaikan oleh Mc. Kernan seperti terlihat pada gambar berikut.

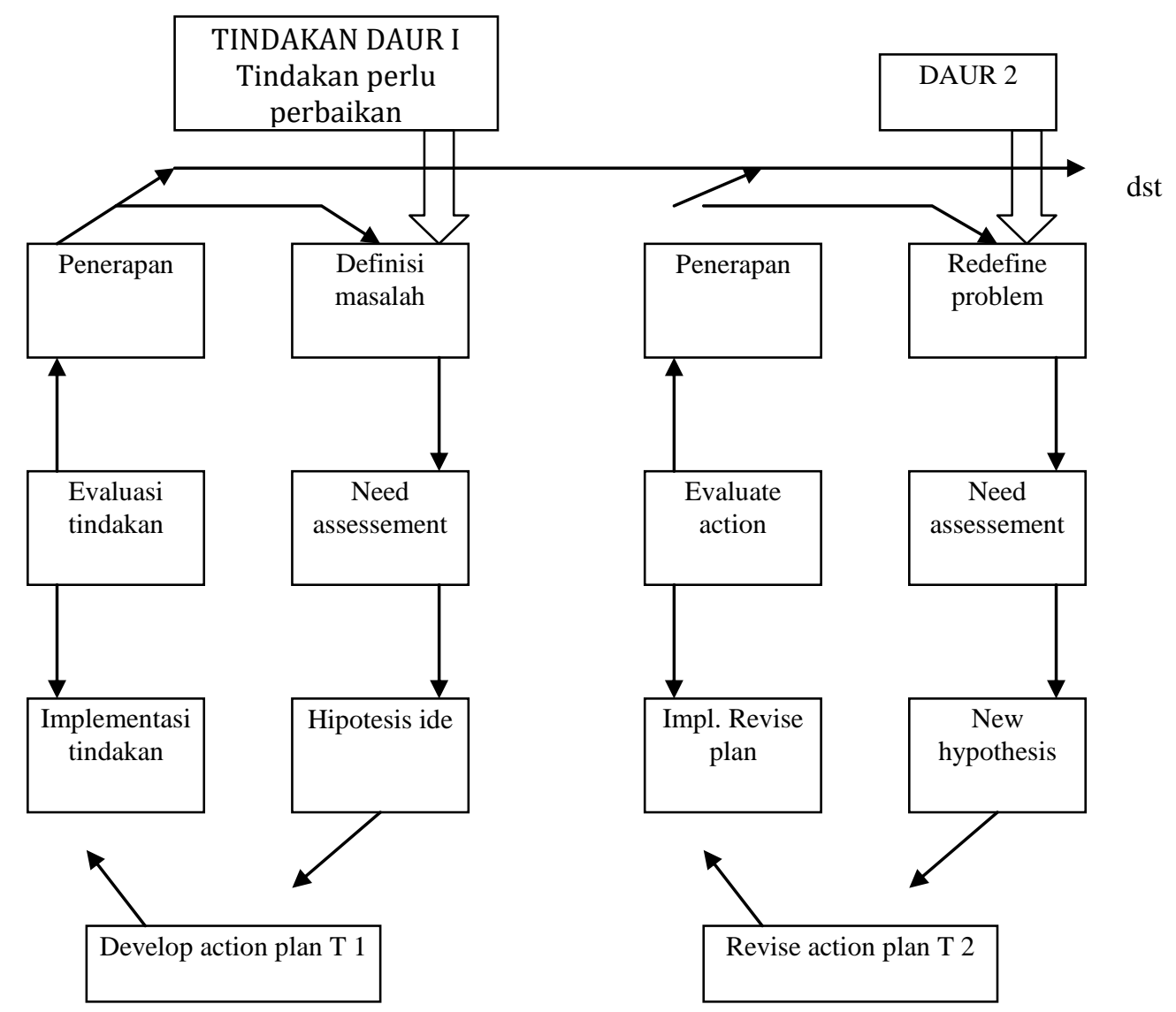

Gambar 1. Penelitian Tindakan Model Mc. Kernan, 1991 (dalam Sukidin, Basrowi, Suranto, 2002: 54)

Prosedur:

1. Tindakan daur I: mulai dari definisi masalah, berlanjut ke assessment yang disiapkan, berlanjut ke rumusan hipotesis, berlanjut ke pengembangan untuk tindakan I, lalu implementasi tindakan, evaluasi tindakan berlanjut ke penerapan selanjutnya.

2. Tindakan daur II: mulai dari menentukan kembali masalah yang ada, berlanjut ke assessment yang disiapkan, terus ke pemikiran terhadap munculnya hipotesis yang baru, perbaikan tindakan pada rencana ke 2, pelaksanaan tindakan, evaluasi terhadap semua pelaksanaan dan penerapan.

Pengumpulan data dalam penelitian ini menggunakan tes prestasi belajar. Tes prestasi belajar berupa tes soal isian maupaun esay. Untuk menganalisis data hasil penelitian ini digunakan metode deskriptif. Untuk data kuantitatif dianalisis dengan mencari mean, median, modus, membuat interval kelas dan melakukan penyajian dalam bentuk tabel dan grafik. Indikator keberhasilan penelitian yang diusulkan dalam penelitian ini pada siklus I dan II mencapai nilai rata-rata 75,00 dengan ketuntasan belajar 85\%. dengan KKM yang ditetapkan untuk mata pelarajan PPKn pada SMP Negeri 1 Blahbatuh adalah 75.

\section{Hasil dan Pembahasan}

Penelitian Model pembelajaran Pair Check merupakan model pembelajaran berkelompok yang saling berpasangan yang dipopulerkan oleh Spencer Kagan pada tahun 1990. Model ini menerapkan pembelajaran kooperatif yang menuntut kemandirian dan kemampuan siswa dalam menyelesaikan persoalan. Model ini juga melatih tanggung jawab sosial siswa, kerja sama, dan kemampuan memberi penilaian (Huda, 2013: 211). Sedangkan, model cooperative learning tipe pair check adalah modifikasi dari tipe think pairs share, dimana penekanan pembelajaran ada pada saat mereka diminta untuk saling cek jawaban atau tanggapan terhadap pertanyaan guru saat berada dalam pasangan (Faiq, 2013). 
Model ini juga merupakan model pembelajaran berpasangan (Aqib, 2013: 34). Model ini menerapkan pembelajaran kooperatif yang menuntut kemandirian dan kemampuan siswa dalam menyelesaikan persoalan. Metode ini juga melatih tanggungjawab sosial siswa, kerja sama dan kemampuan memberi penilaian (Huda, 2013: 211). Menurut Sanjaya (2007) dijelaskan bahwa, "Pembelajaran pair check adalah suatu tipe pembelajaran kooperatif yang berpasangan (kelompok sebangku) yang bertujuan untuk mendalami atau melatih materi yang telah dipelajarinya".

Berdasarkan penelitian yang telah dilakukan dengan menerapkan model pembelajaran Pair Check didapatkan hasil sebagai berikut. Deskripsi yang dapat disampaikan untuk perolehan data awal sebagai indikator yang dituntut yaitu minimal siswa mampu mencapai ketuntasan belajar dengan nilai sama atau melebihi KKM. KKM yang dipatok berdasarkan ketentuan yang disepakati oleh dewan Guru dan Komite untuk mata pelajaran PPKn adalah 75,00. Data yang diperoleh menunjukkan hanya 20 orang siswa yang tuntas diantaranya 0 orang yang melampaui KKM dan 20 orang setara dengan KKM, secara klasikal jumlah nilai diperoleh adalah 2645 dengan rata rata kelas adalah 67,82 atau hanya 51,28\% yang tuntas dari siswa dikelas IX A pada semester I tahun pelajaran 2018/2019. Data tersebut menunjukkan rendahnya prestasi belajar siswa kelas IX A pada proses pembelajaran awal. Kekurangan yang ada adalah akibat pembelajaran yang dilukan masih bersifat konfensional, kurang alat peraga dan kurang inovatif. Kelebihannya adalah peneliti sebagai guru telah giat melakukan pembelajaran secara maksimal

Pada siklus I adalah hanya 30 siswa atau 76,92\% yang memperoleh nilai sesuai atau melebihi dengan KKM di sekolah ini. Sedangkan yang lainnya yang berjumlah 9 siswa atau 23,07\% belum mampu mencapai KKM yang dituntut. Data tersebut menunjukkan siswa-siswa tersebut belum giat dalam mengikuti proses pembelajaran oleh karena itu peneliti harus lebih giat lagi melakukan pembelajaran pada siklus berikutnya.

Hasil ini meningkat pada sikluls II. Pada siklus II ini adalah dari 39 siswa yang diteliti ternyata hasilnya sudah sesuai dengan harapan yaitu dengan perolehan rata-rata kelas 80,12. Dari perkembangan tersebut diketahui hampir semua siswa telah mampu mengikuti pembelajaran dengan baik.

Rangkuman hasil penelitian pada penelitian ini dapat digambarkan pada gambar berikut.

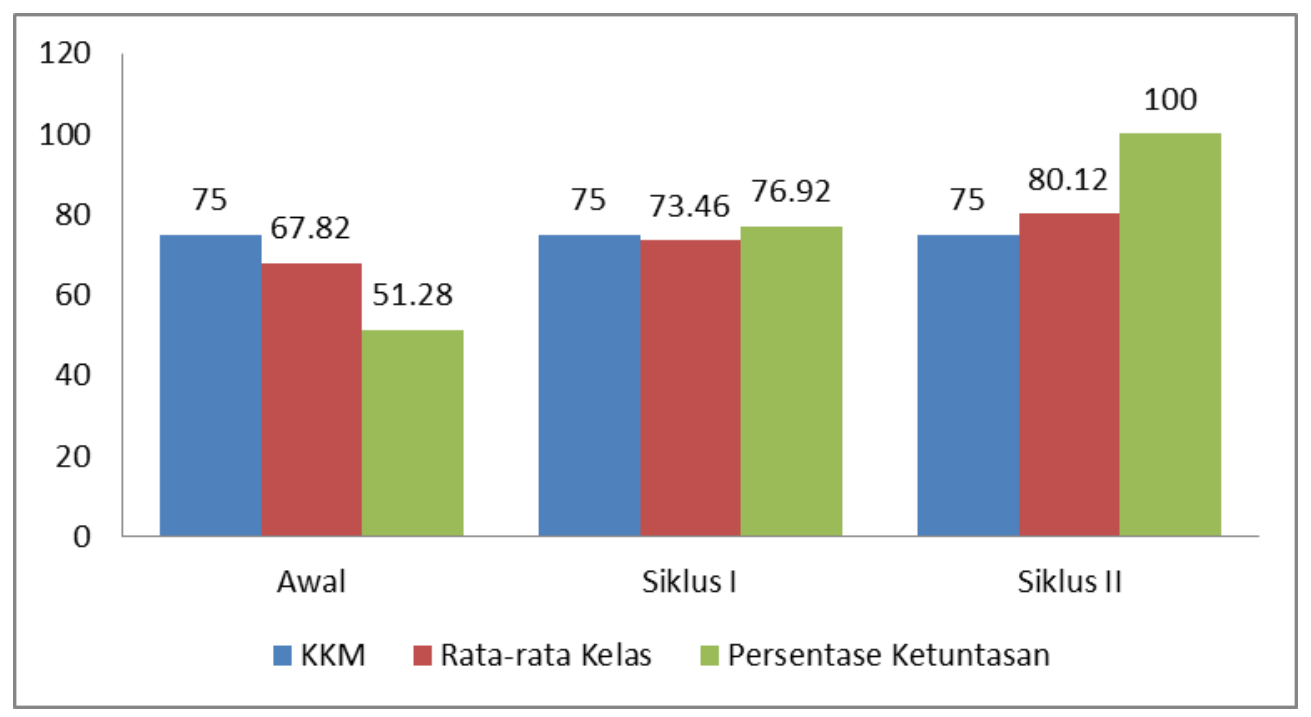

Gambar 2. Grafik Histogram Rangkuman Hasil Penelitian

Hasil pada penelitian ini sesuai dengan hasil penelitian yang telah dilakukan oleh Pratiwi pada tahun 2018 dengan judul Peningkatan Hasil Belajar PKN Pada Pokok Bahasan Kebebasab Berorganisasi Melalui Model Pair Checks. Hasil penelitian menunjukkan bahwa pada siklus I persentase aktivitas belajar siswa $(69,05 \%)$ dan terjadi peningkatan pada siklus II yaitu $(81,53 \%)$. Maka aktivitas siswa mengalami peningkatan sebesar $(12,48 \%)$. Hasil belajar siswa pada tahap siklus I presentase ketuntasan belajar siswa hanya mencapai (36,73\%). Sedangkan pada tahap siklus II presentase ketuntasan hasil belajar siswa meningkat menjadi (86,27\%), maka hasil belajar siswa dari siklus I ke siklus II mengalami peningkatan sebesar (49,54\%). Dengan demikian penerapan model pair checks terbukti dapat meningkatkan hasil belajar siswa pada mata pelajaran Pendidikan Kewarganegaraan pokok bahasan kebebasan berorganisasi.

Selanjutnya penelitian yang dilakukan oleh Kurniawan, dkk pada tahun 2017 dengan judul Pengaruh Model Pembelajaran Pair Check terhadap Hasil Belajar Pkn Siswa SD. Hasil penelitian 
menunjukkan bahwa nilai rata-rata posttest kelas $\mathrm{V}$ A adalah 78,5, sedangkan nilai rata-rata kelas $\mathrm{V} B$ adalah 72,7. Berdasarkan hasil pehitungan uji hipotesis menunjukan nilai sig (2-tailed) 0,026, $(0,026<$ 0,05) sehingga HO ditolak. Dari perhitungan tersebut dapat diperoleh bahwa model pembelajaran pair check dapat mempengaruhi hasil belajar siswa.

\section{Simpulan Dan Saran}

Penelitian Berdasarkan penelitian yang telah dilakukan, dapat disimpulkan bahwa: Penggunaan Model Pembelajaran Pair Check dapat meningkatkan Prestasi Belajar PPKN Melalui Pada Siswa Kelas IX A SMP Negeri 1 Blahbatuh Semester I Tahun Pelajaran 2018/2019.

Sesuai dengan simpulan dari hasil penelitian, dalam upaya mencapai tujuan pembelajaran dalam bidang studi PPKN, dapat disampaikan saran-saran sebagai berikut.

1. Kepada teman guru pengajar mata pelajaran PPKN disarankan mencoba Model Pembelajaran Pair Check.

2. Kepada Kepala Sekolah disarankan untuk untuk memberi penekanan agar guru mau melaksanakan pembelajaran dengan langkah-langkah metode yang sudah diteliti.

3. Dalam melaksanakan proses pembelajaran pada mata pelajaran PPKN, penggunaan Model Pembelajaran Pair Check semestinya menjadi pilihan dari beberapa metode yang ada mengingat metode ini telah terbukti dapat meningkatkan kerjasama, berkreasi, bertindak aktif, bertukar informasi, mengeluarkan pendapat, bertanya, berdiskusi, berargumentasi dan lain-lain.

4. Walaupun penelitian ini sudah dapat membuktikan efek utama dari Model Pembelajaran Pair Check dalam meningkatkan prestasi belajar, sudah pasti dalam penelitian ini masih ada hal-hal yang belum sempurna dilakukan, oleh karenanya kepada peneliti lain yang berminat meneliti topik yang sama untuk meneliti bagian-bagian yang tidak sempat diteliti.

5. Demi kesempurnaan penelitiaan ini, peneliti mengharapkan kritik, saran, masukan yang konstruktif sehingga diharapkan bagi peneliti lain untuk melakukan penelitian lanjutan.

\section{Daftar Rujukan}

Amri, Sofan. 2013. Peningkatan Mutu Pendidikan SMP dan Menengah. Jakarta: PT. Prestasi Pustakaraya.

Arikunto, Suharsimi; Suhardjono; Supardi. 2006. Penelitian Tindakan Kelas. Jakarta: PT Bumi Aksara.

Badan Standar Nasional Pendidikan. 2007. Peraturan Menteri Pendidikan Nasional Republik Indonesia Nomor 41 Tahun 2007. Jakarta: BSNP.

Charuer, Kathy, dkk. 2005. Permainan Berbasis Sentra Pembelajaran. Beltsuillee, MD 20705: Translation Copyright 2005 by Penerbit Erlangga.

Dahar, Ratna Wilis. 1989. Teori-Teori Belajar. Jakarta: Penerbit Erlangga.

Daryanto. 1999. Evaluasi Pendidikan. Rineka Cipta: Jakarta.

Depdiknas, 2003c. Sistem Penilaian Kelas SMP, SMP, SMA dan SMK. Dirjen Dikdasmen Tendik

Depdiknas. 2008. Pengolahan dan Analisis Data Penelitian. Jakarta: Direktorat Tenaga Kependidikan Dirjen PMPTK.

Depdiknas. 2011. Membimbing Guru dalam Penelitian Tindakan Kelas. Jakarta: Pusat Pengembangan Tenaga Kependidikan Badan Pengembangan Sumber Daya Manusia Pendidikan dan Menjaminan Mutu Pendidikan.

Dimyati dan Mudjiono. 2001. Belajar dan Pembelajaran. Jakarta: Dirjen Dikti.

Djamarah, Syaful Bahri. 2002. Prestasi Belajar dan Kompetensi Guru. Surabaya: Usaha Nasional.

Hartinah DS, Haji Sitti. 2009. Konsep Dasar Bimbingan Kelompok. Bandung: PT. Refika Aditama. 
Kurniawan, dkk. 2017. Pengaruh Model Pembelajaran Pair Check terhadap Hasil Belajar Pkn Siswa SD. Jurnal Pedagogi Volume 6 Nomor 6.

Pratiwi, Yuniar Ayu. 2018. Peningkatan Hasil Belajar PKN Pada Pokok Bahasan Kebebasab Berorganisasi Melalui Model Pair Checks. Jurnal Ibtida'i Volume 5 No. 01.

Saat, Sulaiman . 2015. Faktor-Faktor Determinan Dalam Pendidikan (Studi Tentang Makna Dan Kedudukannya Dalam Pendidikan) . Jurnal Al-Ta'dib Vol. 8 No. 2, Juli-Desember.

Thahir, Andi. 2014. Pengaruh Bimbingan Belajar Terhadap Prestasi Belajar Siswa Pondok Pesantren Madrasah Aliyah Al-Utrujiyyah Kota Karang . Jurnal Bimbingan dan Konseling 01 (2) (2014).

Wijayanti, Takdir Sukmo . 2014. Meningkatkan Minat Dan Prestasi Belajar Matematika Dengan Model Pembelajaran Group Investigation Siswa Kelas Vii A Smp Negeri 1 Polanharjo Klaten . Jurnal Pendidikan Matematika Vol 2 No 1, November 2014. 